\title{
Methane Emissions From Natural Wetlands
}

Judy L. Meyer

University of Georgia
Roger A. Burke, Jr.

U.S. Environmental Protection Agency

\section{Background}

Analyses of air trapped in polar ice cores in conjunction with recent atmospheric measurements, indicate that the atmospheric methane concentration increased by about $250 \%$ during the past two or three hundred years (Rasmussen and Khalil, 1984). Because methane is a potent "greenhouse" gas, the increasing concentrations are expected to contribute to global warming (Dickinson and Cicerone, 1986). The timing of the methane increase suggests that it is related to the rapid growth of the human population and associated industrialization and agricultural development. The specific causes of the atmospheric methane concentration increase are not well known, but may relate to either increases in methane sources, decreases in the strengths of the sinks, or both.

\section{Sources}

Sources accounting for about $70 \%$ of the total atmospheric methane source are fully (e.g., coal mining and natural gas production, landfills, domestic sewage treatment, rice paddies) or largely (e.g., biomass burning, animal wastes) under anthropogenic control (Watson et al., 1992). Natural wetlands appear to be an important atmospheric methane source; however, the present size of this source is difficult to evaluate because of uncertainties in measures of both the flux of methane from and the areal extent of natural wetlands. The most recent IPCC (Intergovernmental Panel on Climate Change) assessment estimates that natural wetlands contribute about $22 \%$ of the total atmospheric methane source (Watson et al., 


\section{DISCLAIMER}

Portions of this document may be illegible in electronic image products. Images are produced from the best available original document. 
1992). Methane emissions from natural wetlands have been found to be highly variable ( $<1$ to $>1000 \mathrm{mg} \mathrm{CH}_{4} \mathrm{~m}^{-2} \mathrm{~d}^{-1}$ ) on seasonal (Harriss et al., 1982; DeLaune et al., 1983) and various spatial scales (e.g., Bartlett et al., 1989). Factors that can contribute to variations in methane flux from wetlands include wind speed, temperature, atmospheric pressure, $\mathrm{pH}$, moisture content or water table level, substrate type and concentration, concentration of inhibitors, soil redox potential, and the type, physiological state, photosynthetic rate, and biomass of wetland plants (e.g., Barber et al., 1988; Pulliam and Meyer, 1992; Mattson and Likens, 1990; Williams and Crawford, 1984; Burke et al., 1988a; Whiting and Chanton, 1992).

Intensive agricultural practices accompanying human population growth have altered the natural hydrology and vegetation and increased inputs of nutrients (e.g., phosphate, nitrate, and ammonia) into many natural wetland systems (e.g., Conner et al., 1981). Harriss and Sebacher (1981) found that methane flux from a Florida cypress dome receiving regular input of secondary sewage effluent was 4 to 100 times greater than methane flux from undisturbed forested freshwater swamps of the southeastern U.S. This increase in methane flux was attributed to an acceleration of organic production, which in turn, resulted in increases in sedimentary organic matter and phosphorus (Harriss and Sebacher, 1981). Whiting et al. (1991) observed that methane flux was linearly correlated with live plant biomass and net ecosystem $\mathrm{CO}_{2}$ exchange (NEE) at two locations (one burned and one unburned) in a Florida Everglades sawgrass marsh. Both methane flux and NEE per unit of live plant biomass were greater in the burned plot; however, one relationship between NEE and methane flux was found for both sites (Whiting et al., 1991). It was suggested that the methane flux-NEE relationship is observed because the rate of production of root exudates, which probably are degraded to methanogenic substrates, depends upon the rate of photosynthesis (Whiting et al., 1991). Fires are known to release nutrients to the water and soil (e.g., Hofstetter, 1984; Levine et al., 1990), which could stimulate enhanced photosynthesis, and thus methane production, as a result of fertilization. A 
similar fertilization effect on plant primary production and methane production (Whiting et al., 1991; Whiting and Chanton, 1992) could also result from agricultural inputs.

Sinks

On the other side of the ledger, Khalil and Rasmussen (1985) calculated that possibly $30 \%$ of the methane increase was due to a decline in the atmospheric concentration of hydroxyl radicals. An additional sink, uptake by soils, is estimated to account for the removal of about $30( \pm 15) \mathrm{Tg} \mathrm{CH}_{4}$ per year, or about 3 to $10 \%$ of the total uptake (Watson et al., 1992). Thus the soil sink is nearly equivalent to the atmospheric increase of $32( \pm 5) \mathrm{Tg} \mathrm{CH}$ per year. Measurements of methane uptake by dry soils are much less common than measurements of methane emissions from wetlands. Those measurements that are available indicate that dry soils in a wide variety of ecosystems consume methane, including tropical (e.g., Keller et al., 1990), temperate (e.g., Crill, 1991) and boreal (Whalen et al., 1991) forests, tundra (Whalen and Reeburgh, 1990), temperate grasslands (e.g., Mosier et al., 1991), savannas (e.g., Delmas et al., 1991) and deserts (Striegl et al., 1992). Results of these and other studies indicate that the strength of the soil sink varies from $<1$ to about $10 \mathrm{mg} \mathrm{CH}_{4}$ $\mathrm{m}^{-2} \mathrm{~d}^{-1}$. The rate of methane uptake by soils is generally less influenced by bacterial activity than methane production, but rather is usually limited by the physical transport of methane into the soil (Bom et al., 1990; Crill, 1991). The rate of physical transport of methane into the soil is, in turn, dependent upon soil parameters such as porosity, moisture level, and tortuosity and on the molecular diffusion coefficient of methane in air (Bom et al., 1990). This physical transport dependence probably accounts for the fact that measured rates of soil methane consumption span a more narrow range than soil methane emission rates. Soil parameters such as moisture level can vary periodically or seasonally, however, and make it difficult to determine the role of soils in the atmospheric methane cycle. For example, Harriss et al. (1982) 
reported that Great Dismal Swamp soils are a net source of atmospheric methane during the times of the year when they are waterlogged, and a net atmospheric methane sink when they dry out.

The soil sink is also subject to human perturbation; recent studies indicate that physical changes in soil properties (e.g., decreases in soil porosity due to compaction) resulting from changes in land use (Keller et al., 1990; Scharffe et al., 1990) and enhanced nitrogen fertilization (Steudler et al., 1989; Mosier et al., 1991) are decreasing the uptake of atmospheric methane by soils. Soil compaction (e.g., Keller et al., 1990) decreases the rate of physical transport into the soil. The fertilization effect appears to be competitive inhibition of methane consumption by some methanotrophs via the input of nitrogen compounds, in particular, ammonium (Steudler et al., 1989).

Objectives

The overall objectives of this project are to investigate (1) the influence of agricultural disturbances, both physical and chemical, on the exchange of methane between the atmosphere and soils of riparian ecosystems, and (2) the environmental conditions regulating methane exchange. Our approach is to conduct seasonal field studies of soil/atmosphere methane exchange at sites in the piedmont and coastal plain provinces of the southeastern United States.

\section{Field Sites}

The landscape of the southeastern piedmont region, which extends from Virginia to Alabama, is composed of a diverse range of land uses, including forest, pasture, row crop, and urban categories. The University of Georgia (UGA) Horseshoe Bend Agroecosystems research area is located on the upper (50 to 100-year) floodplain of the Oconee River in Athens, Georgia. The HSB experimental area provides an opportunity to assess the effect of several land management practices on soil/atmosphere methane exchange. Land use types include areas managed as row crops, mowed fescue sod, abandoned fields, and undeveloped mixed hardwood riparian 
forests. The soil in the HSB row crops area is a well-drained sandy clay loam floodplain soil with $66 \%$ sand, $13 \%$ silt, and $21 \%$ clay (Groffman et al., 1986). The soil from a site within the riparian forest was found to consist of $80 \%$ sand, $18 \%$ silt, and $2 \%$ clay (Huhta et al., 1989). Our measurements of five sites within the forest area indicate that the forest soil consists of about 60 to $80 \%$ sand, 10 to $20 \%$ silt, and 10 to $20 \%$ clay.

Within the row crops category, areas of conventional (CT) and no-tillage (NT) have been maintained since 1978. From 1978 and 1991 a summer crop of soybeans or sorghum was planted in the $\mathrm{CT}$ and $\mathrm{NT}$ plots and generally fertilized with $\mathrm{NH}_{4} \mathrm{NO}_{3}$ at a rate of 50 to $100 \mathrm{~kg} \mathrm{ha}^{-1}$. Winter crops during this period consisted of either rye or crimson clover. In the spring of 1992, the CT and NT plots were planted in corn with no fertilizer applied. Due to unusually wet conditions, no winter crop was planted this year.

The UGA Coastal Plain Experiment station near Tifton, Georgia is located in the Little River Watershed in the Tifton upland subprovince of the Georgia coastal plain. The station includes conventional and no-till agricultural areas in upland areas and mixed hardwood/pine riparian forests on first, second, and third order streams in the bottomlands. Riparian forests are a significant part of the landscape, accounting for about $30 \%$ of the area of one typical subwatershed (Lowrance et al., 1984).

We are currently making methane flux measurements at two areas within the Coastal Plain Experiment station. One area is a riparian buffer system that separates a second order, intermittent stream and a field with conventionally-tilled com-peanut rotations receiving annual inputs of $200 \mathrm{~kg} \mathrm{~N} \mathrm{ha}^{-1}$ and $100 \mathrm{~kg} \mathrm{P} \mathrm{ha}^{-1}$ (Gibbs Farm). Longleaf and slash pine dominate the drier forested area with a mixture of yellow poplar and black gum near the stream. The second area within the Coastal Plain Experiment station is a small wetland (dairy wetland) that is associated with a first order steam and serves as a riparian buffer between a Low Input Sustainable 
Agriculture (LISA) site and a small pond. The LISA site is an agricultural field that is divided into quadrants. The quadrant that most influences the dairy wetland receives about $600 \mathrm{~kg} \mathrm{ha}^{-1} \mathrm{yr}^{-1}$ of $\mathrm{N}$ as liquified cattle waste (Vellidis et al., in press). We have established a control site about $30 \mathrm{~km}$ from the Coastal Plain Experiment station in an undeveloped riparian wetland near Ashburn, Georgia on private land.

\section{Analytical Techniques}

We use a static chamber technique (e.g., Whalen and Reeburgh, 1988) to estimate soil/atmosphere exchange. The chamber consists of a permanently-deployed square aluminum collar, which encloses and area of about $0.5 \mathrm{~m}^{2}$, with a water seal and skirt $(\sim 7 \mathrm{~cm}$ deep in agricultural soils, $\sim 3$ to $4 \mathrm{~cm}$ deep in forest soils to minimize root damage). The lid is constructed of either acrylic plastic or aluminum and is equipped with a septum for syringe sampling and a small hole to equalize pressure. The total volume enclosed is about 7.5 liters, and methane flux is calculated from the change in the methane content of the chamber headspace with time during a typical deployment of 30 minutes. The methane content of the chamber headspace is analyzed with a Carle Series 100 AGC gas chromatograph (GC), which is equipped with a flame ionization detector, and a Hewlett-Packard Model 3394A integrator. Methane concentration measurements are referenced to NIST Standard Reference Material 1658a, which has a methane concentration of $0.982 \mathrm{ppmv}$, and a tank of breathing air ( 2.64 ppmv methane) that has been calibrated against the NIST SRM. Air temperature and soil temperatures (at depths of 1,5, and $10 \mathrm{~cm}$ ) are measured with a thermocouple probe. The limit of detection of this system is estimated to be about $0.3 \mathrm{mg} \mathrm{CH}_{4} \mathrm{~m}^{-2} \mathrm{~d}^{-1}$. Gravimetric soil moisture is measured by weight loss after drying at $105^{\circ} \mathrm{C}$ and is expressed as per cent water on a dry soil basis ([grams water / grams dry soil] $X 100$ ).

Results to date 


\section{Horseshoe Bend}

Soil-atmosphere methane exchange is presently being measured at intervals of roughly ten days at fifteen sites within the HSB area. The sites being monitored consist of five sites each from a mixed hardwood forest, a CT agricultural area and an NT agricultural area. Two of the forest sites (\#s 11 and 12) are about 1 meter lower in elevation and have a thinner leaf litter layer $(1$ to $2 \mathrm{~cm}$ ) than the other three (\#s 13 , 14, and 15) sites (litter layer about 3 to $5 \mathrm{~cm}$ thick). Methane flux measurements completed to date at the forest sites are presented in Figures 1 and 2. The median net soil/atmosphere methane exchange at both sites 11 and 12 is $0 \mathrm{mg} \mathrm{CH}_{4} \mathrm{~m}^{-2} \mathrm{~d}^{-1}$ with generally little variation (Figure 1). Median consumption rates for forest sites 13, 14, and 15 are $-0.8,-1.33$. and $-1.25 \mathrm{mg} \mathrm{CH}_{4} \mathrm{~m}^{-2} \mathrm{~d}^{-1}$, respectively. Methane consumption rates at these forest sites exhibit considerable temporal variation but the variation is not distinctly seasonal (Figure 2). A non-parametric multiple comparison test (Dunn's test) indicates that the forest sites can be separated into two groups (Figure 3), with the group consisting of sites 11 and 12 showing essentially no net methane exchange with the atmosphere.

Median methane exchange rates for all ten sites within the CT and NT plots are $0 \mathrm{mg} \mathrm{CH} \mathrm{m}^{-2} \mathrm{~d}^{-1}$. The Dunn's non-parametric multiple comparison test indicates no significant difference in methane exchange rates among the sites within the CT and NT categories and no significant difference between the CT and NT plots with respect to methane exchange. Further, the Dunn's test indicates no significant difference in methane exchange characteristics among the CT plots, NT plots, and the forest group consisting of site \#s 11 and 12 (Figure 4). A significant difference in methane exchange characteristics between the forest group consisting of site \#s 13,14, and 15 and the other groups is indicated, however as observed in other studies of the effects of disturbance on the methane exchange characteristics of forest soils.

Coastal Plain Experiment Station 
We have completed one sampling trip to these sites during each of the seasons, spring, summer, fall, and winter. The methane flux measurements resulting from these first four sampling trips are summarized in Figures 5. The Gibbs Farm and dairy wetland soils are generally wetter than the HSB soils and are generally a weak source of methane to the atmosphere. Application of the Kruskal-Wallis one way ANOVA on ranks to our data indicates no significant seasonal influence on methane flux at either the Gibbs Farm site (top panel of Figure 5) or the control site (bottom panel of Figure 5). The only indicated seasonal difference (Dunn's test) is between the 12/92 and 3/93 dairy wetland sample groups (middle panel of Figure 5). Hydrological conditions were similar and favorable for emissions of methane from the soil to the atmosphere during both the $12 / 92$ and $3 / 93$ sampling trips, with the water table at or above the soil surface at all of the dairy wetland gas flux sampling sites. Soil and water temperatures during $12 / 92$ trip were considerably lower $\left(9\right.$ to $12^{\circ} \mathrm{C}$ ), however, than during the 3/93 trip when soil and water temperatures varied between about 17 and $19^{\circ} \mathrm{C}$. Numerous studies have demonstrated correlations between methane production (e.g., Williams and Crawford, 1984) or emission and temperature. Two studies have shown a dramatic increase in methane emissions as temperature increases through the range of 10 to $15^{\circ} \mathrm{C}$ in swamp (Wilson et al., 1989) and floodplain soils (Pulliam and Meyer, 1992). Application of Dunn's test to our pooled data from each site (Figure 6) indicates that (1) the methane flux from dairy wetland soils is significantly greater than that from either the Gibbs Farm or Control site soils, and (2) there is no significant difference in soil/atmosphere methane exchange between the Gibbs Farm and Control site.

Our Gibbs Farm sites are located varying distances from the intermittent stream. Sites 2 and 3 , which are located within about 5 meters of the stream tend to be wetter (soil moisture ranges from 80 to $110 \%$ ) and emit more methane 0 to $65 \mathrm{mg}$ $\mathrm{CH}_{4} \mathrm{~m}^{-2} \mathrm{~d}^{-1}$ than sites 4,5 , and 6 (soil moisture ranges from about 20 to $60 \%$ ), which are about 10 to 15 meters from the stream and exchange about $1 \mathrm{mg} \mathrm{CH}_{4} \mathrm{~m}^{-2} \mathrm{~d}^{-1}$ with 
the atmosphere. Our measurements to date indicate that, when flooded, the intermittent stream emits between about 1 and $30 \mathrm{mg} \mathrm{CH}_{4} \mathrm{~m}^{-2} \mathrm{~d}^{-1}$ (OW (open water) column of Table 1).

Although temperatures were favorable $\left(24\right.$ to $26^{\circ} \mathrm{C}$ ) for rapid methane production during 7/92 and 9/92, standing water was not present at any of the dairy wetland gas exchange sampling locations. Soil moisture levels ranged from about 20 to $140 \%$. Methane exchange rates for these two trips ranged between -0.5 and $36 \mathrm{mg}$ $\mathrm{CH}_{4} \mathrm{~m}^{-2} \mathrm{~d}^{-1}$ with no obvious relation to soil moisture.

Our Ashburn control sites are located at varying distances (one to five meters) from a small, apparently permanent stream. The forest surrounding this site is composed predominantly of pines, with deciduous riparian species right next to the stream. In general, these sites exchange methane only weakly with the atmosphere.

\section{Summary}

Our studies to date indicate that the HSB soils disturbed by agricultural practices are not an atmospheric methane sink. It is difficult to conclude from this observation that the agricultural activity destroyed the sink capacity, however, as one group of HSB forest soils that we studied was a significant sink of atmospheric methane whereas another group of forest soils were observed to not be a sink of atmospheric methane. Maintenance of a stable soil microclimate by the soil litter layer may be a key determinant of a soil's ability to consume atmospheric methane (Keller et al., 1990). If so, the difference in soil litter layer thickness observed between the two HSB forest site groups may at least partially account for the differing methane exchange characteristics. Our Tifton measurements indicate that a regenerating riparian wetland that is indirectly receiving large inputs of liquified cattle waste is a stronger source of methane to the atmosphere than other riparian systems receiving substantially less nutrient input. Addition of the liquified cattle waste has also increased the water input to the dairy wetland by about $30 \%$ (R. Lowrance, personal 
communication. Further, the riparian woody vegetation in the dairy wetland is in a less mature successional state and wetland grasses are currently dominant. We can not rule out the possibility, therefore, that the enhanced methane emissions are due to an elevated water table or to different vegetational characteristics rather than to the intense fertilization.

\section{References}

Barber, T.R., R.A. Burke, and W.M. Sackett. 1988. Diffusive flux of methane from warm wetland environments. Global Biogeochem. Cycles 2:411-425.

Bartlett, D.B., K.B. Bartlett, J.M. Hartman, R.C. Harriss, D.I. Sebacher, R. PelletierTravis, D.D. Dow and D.P. Brannon. 1989. Methane emissions from the Florida Everglades: Patterns of variability in a regional wetland system Global Biogeochemical Cycles 3:363-374.

Born, M., H. Dörr, and I. Levin. 1990. Methane consumption in aerated soils of the temperate zone. Tellus 42B:2-8.

Burke, R.A., T.R. Barber, and W.M. Sackett. 1988a. Methane Flux and Stable Hydrogen and Carbon Isotope Composition of Sedimentary Methane from the Florida Everglades. Global Biogeochem Cycles 2:329-340.

Conner, W.H., J.G. Gosselink and R.T. Parrondo. 1981. Comparison of the Vegetation of Three Louisiana Swamp Sites with Different Flooding Regimes. Ameri. J. Bot. 68(3):320-321.

Crill, P.M. 1991. Seasonal patterns of methane uptake and carbon dioxide release by a 
temperate woodland soil. Global Biogeochemical Cycles 5:319-334.

Delmas, R.A., A. Marenco, J.P. Tathy, B. Cros, and J.G.R. Baudet. 1991. Sources and Sinks of Methane in the African Savanna $\mathrm{CH}_{4}$ Emissions From Biomass Burning. Journal of Geophysical Research 96(D4):7287-7299.

DeLaune, R.D., C.J. Smith, and W.H. Patrick. 1983. Methane release from Gulf Coast wetlands. Tellus 35B:8-15.

Dickinson, R.E. and R.J. Cicerone. 1986. Future global warming from atmospheric trace gases. Nature. 319:109-115.

Groffman, P.M., G.J. House, P.F. Hendrix, D.E. Scott and D.A. Crossley, Jr. 1986. Nitrogen Cycling as Affected by Interactions of Components in a Georgia Piedmont Agroecosystem. Ecology 67(1):80-87.

Harriss, R.C. and D.I. Sebacher. 1981. Methane flux in forested freshwater swamps of southeastern United States. Geophys. Res. Lett. 8:1002-1004.

Harriss, R.C., D.I. Sebacher, and F.P. Day, Jr., Methane flux in the Great Dismal Swamp. Nature. 297:673-674.

Hofstetter, R.H. 1984. The Effect of Fire on the Pineland and Sawgrass Communities of Southern Florida. Pages 465-476 in Environments of South Florida: Present and Past II edited by P.J. Gleason, Miami Geological Society, Miami, FL.

Huhta, V., D.H. Wright, and D.C. Coleman. 1989. Characteristics of defaunated soil. Pedobiologia 33:417-426. 
Keller, M., M.E. Mitre, and R.F. Stallard. 1990. Consumption of atmospheric methane in soils of central Panama: effects of agricultural development. Global Biogeochemical Cycles 4:21-27.

Khalil, M.A.K. and R.A. Rasmussen. 1985. Causes of Increasing Atmospheric Methane: Depletion of Hydroxyl Radicals and The Rise of Emissions. Atmospheric Environment 19(3):397-407.

Levine, J.S., W.R. Cofer, III, D.I. Sebacher, R.P. Rhinehart, E.L. Winstead, S. Sebacher, C.R. Hinkle, P.A. Schmalzer, and A.M. Koller, Jr. 1990. The Effects of Fire on Biogenic Emissions of Methane and Nitric Oxide From Wetlands. Journal of Geophysical Research 95(D2):1853-1864.

Lowrance, R., R. Todd, J. Fail, Jr., O. Hendrickson, Jr., R. Leonard, and L. Asmussen. 1984. Riparian Forests as Nutrient Filters in Agricultural Watersheds. BioScience 34:374-377.

Mattson, M.D., and G.E. Likens. 1990. Air pressure and methane fluxes. Nature 347:718-719.

Mosier, A., D. Schimel, D. Valentine, K. Bronson and W. Parton. 1991. Methane and nitrous oxide fluxes in native, fertilized and cultivated grasslands. Nature 350:330-332.

Pulliam, W.M. and J.L. Meyer. 1992. Methane emissions from floodplain swamps of the Ogeechee river: long-term patterns and effects of climate change. Biogeochemistry 15:151-174. 
Rasmussen, R.A. and M.A.K. Khalil. 1984. Atmospheric methane in recent and ancient atmospheres: concentrations, trends, and interhemispheric gradient. J. Geophys. Res. 89:11599-11605.

Scharffe, D., W.M. Hao, L. Donoso, P.J. Crutzen, and E. Sanhueza. 1990. Soil Fluxes and Atmospheric Concentration of $\mathrm{CO}$ and $\mathrm{CH}_{4}$ in the Northern Part of the Guayana Shield. Journal of Geophysical Research 95(D13):22,475-22,480.

Steudler, P.A., R.D. Bowden, J. Mellilo, and J.D. Aber. 1989. Influence of nitrogen fertilization on methane uptake in temperate forest soils. Nature 341:314-316.

Striegl, R.G., T.A. McConnaughey, D.C. Thorstenson, E.P. Weeks and J.C. Woodward. 1992. Consumption of atmospheric methane by desert soils. Nature 357:145-147.

Vellidis, G., R. Lowrance, M.C. Smith, and R.K. Hubbard. (In Press). Methods to assess the water quality impact of a restored riparian wetland. J. Soil and Water Conservation.

Watson, R.T., L.B. Meira Filho, E. Sanhueza, and A. Janetos. 1992. Greenhouse gases: sources and sinks. Pages 29-46, in J.T. Houghton, B.A. Callander, and S.K. Varney, editors, Climate Change 1992. The Supplementary Report to the IPCC Scientific Assessment, Cambridge University Press, Cambridge.

Whalen, S.C. and W.S. Reeburgh. 1988. A methane flux time series for tundra environments. Global Biogeochem. Cycles 2: 399-409.

Whalen, S.C. and W.S. Reeburgh. 1990. Consumption of atmospheric methane by 
tundra soils. Nature 346:160-162.

Whalen, S.C., W.S. Reeburgh, and K.S. Kizer. 1991. Methane consumption and emission by taiga. Global Biogeochem. Cycles 5: 261-273.

Whiting, G.J. and J.P. Chanton. 1992. Plant-Dependent $\mathrm{CH}_{4}$ Emission in a Subarctic Canadian Fen. Global Biogeochemical Cycles 6(3):225-231.

Whiting, G.J., J.P. Chanton, D.S. Bartlett, and J.D. Happell. 1991. Relationships Between $\mathrm{CH}_{4}$ Emission, Biomass, and $\mathrm{CO}_{2}$ Exchange in a Subtropical Grassland. Journal of Geophysical Research 96(D7):13,067-13,071.

Wilson, J.O., P.M. Crill, K.B. Bartlett, D.I. Sebacher, R.C. Harriss, and R.L. Sass. 1989. Seasonal variation of methane emissions from a temperate swamp. Biogeochemistry 8: 55-71.

Williams, R.T. and R.L. Crawford. 1984. Methane production in Minnesota peatlands. Appl. Environ. Microbiol. 47:1266-1271. 
Figure 1

HSB \# 11

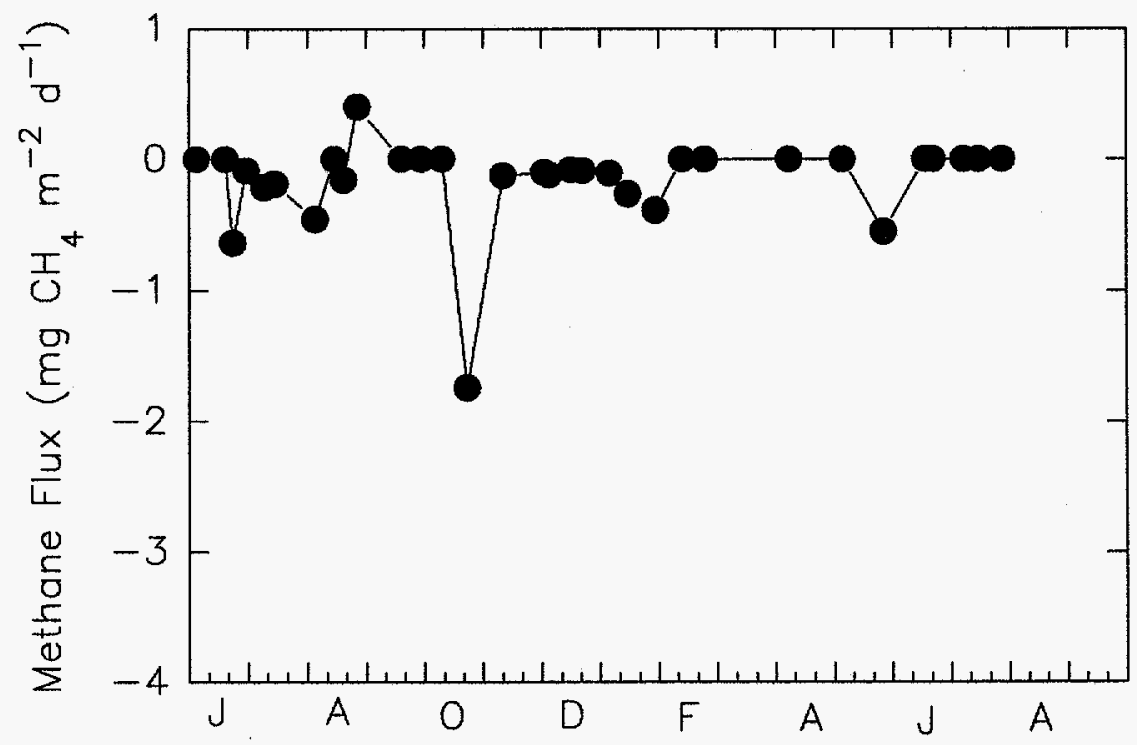

HSB \# 12

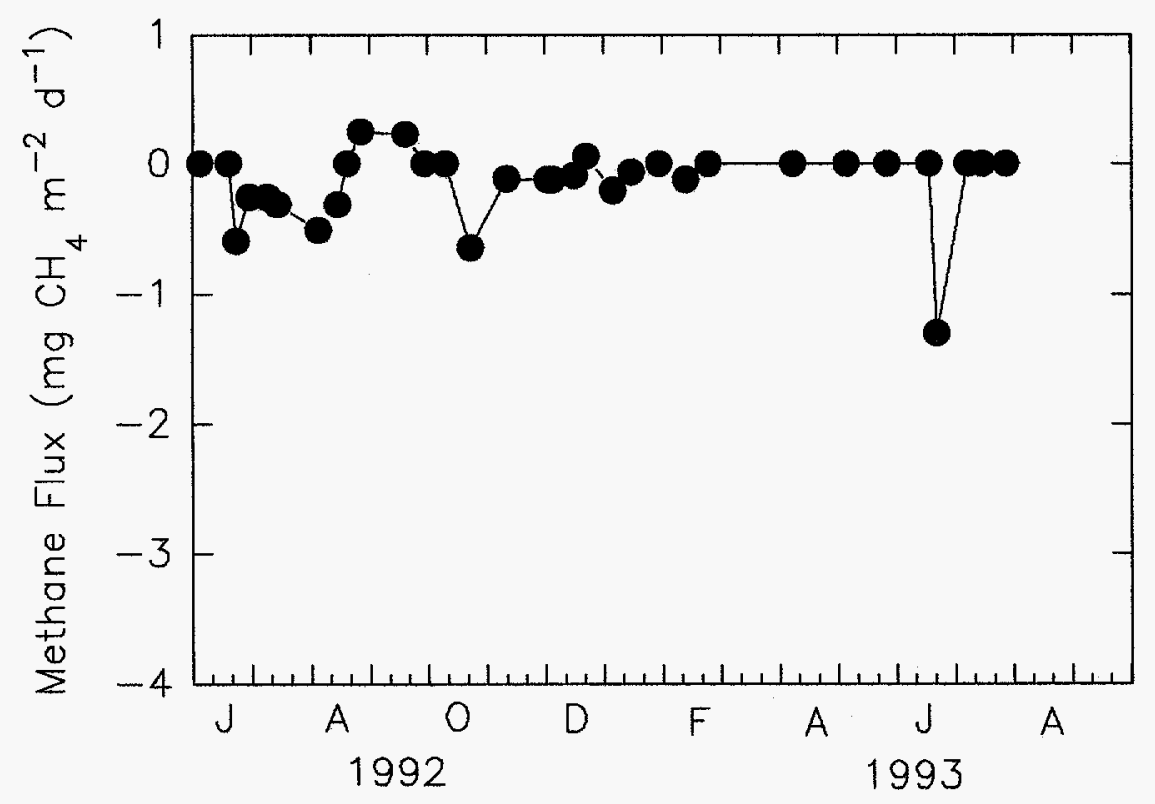


Figure 2

HSB \#13

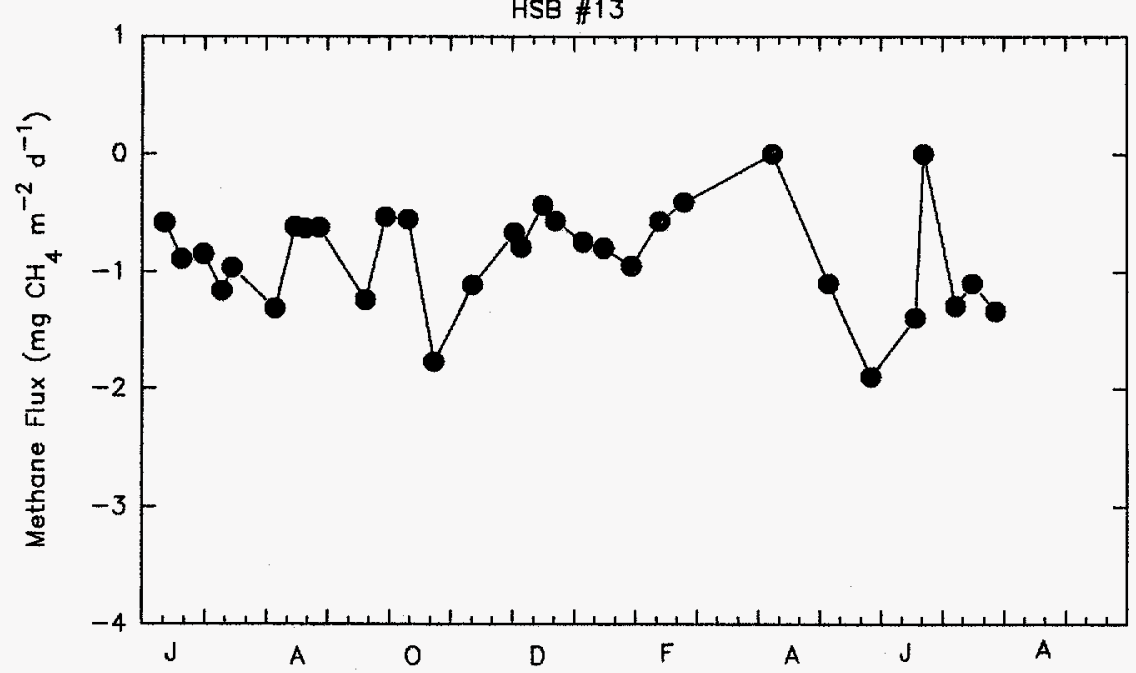

HSB \#14
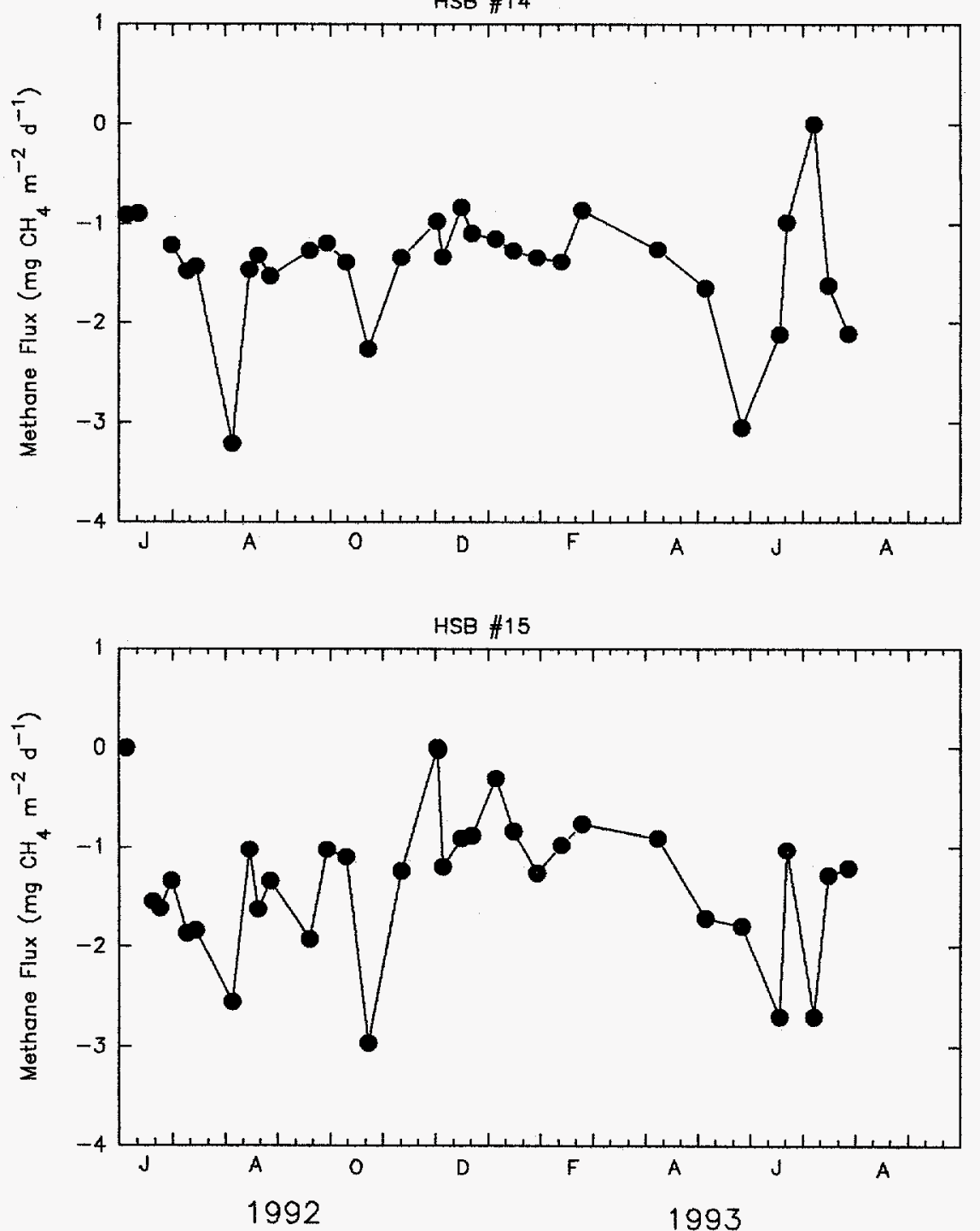
Figure 3

HSB Forest Sites

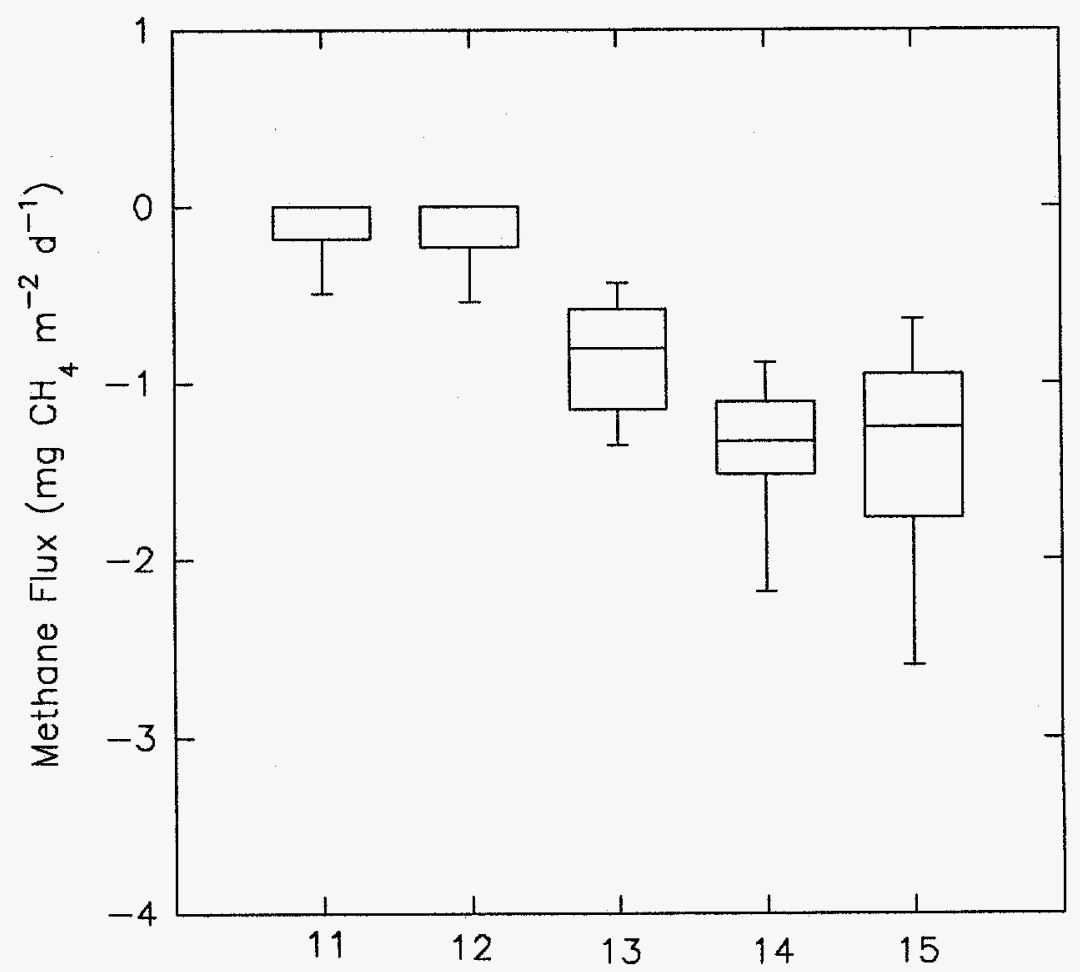

Figure 4

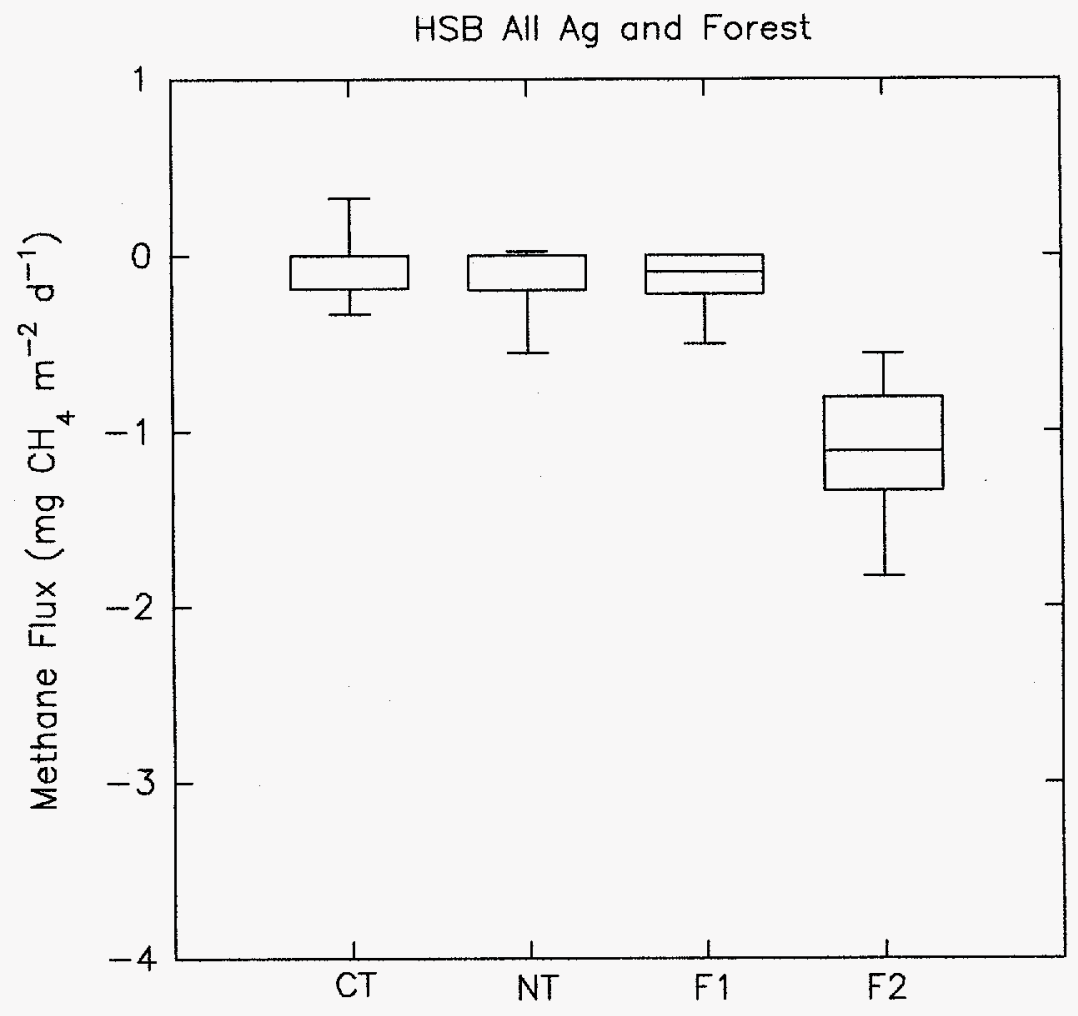


Figure 5
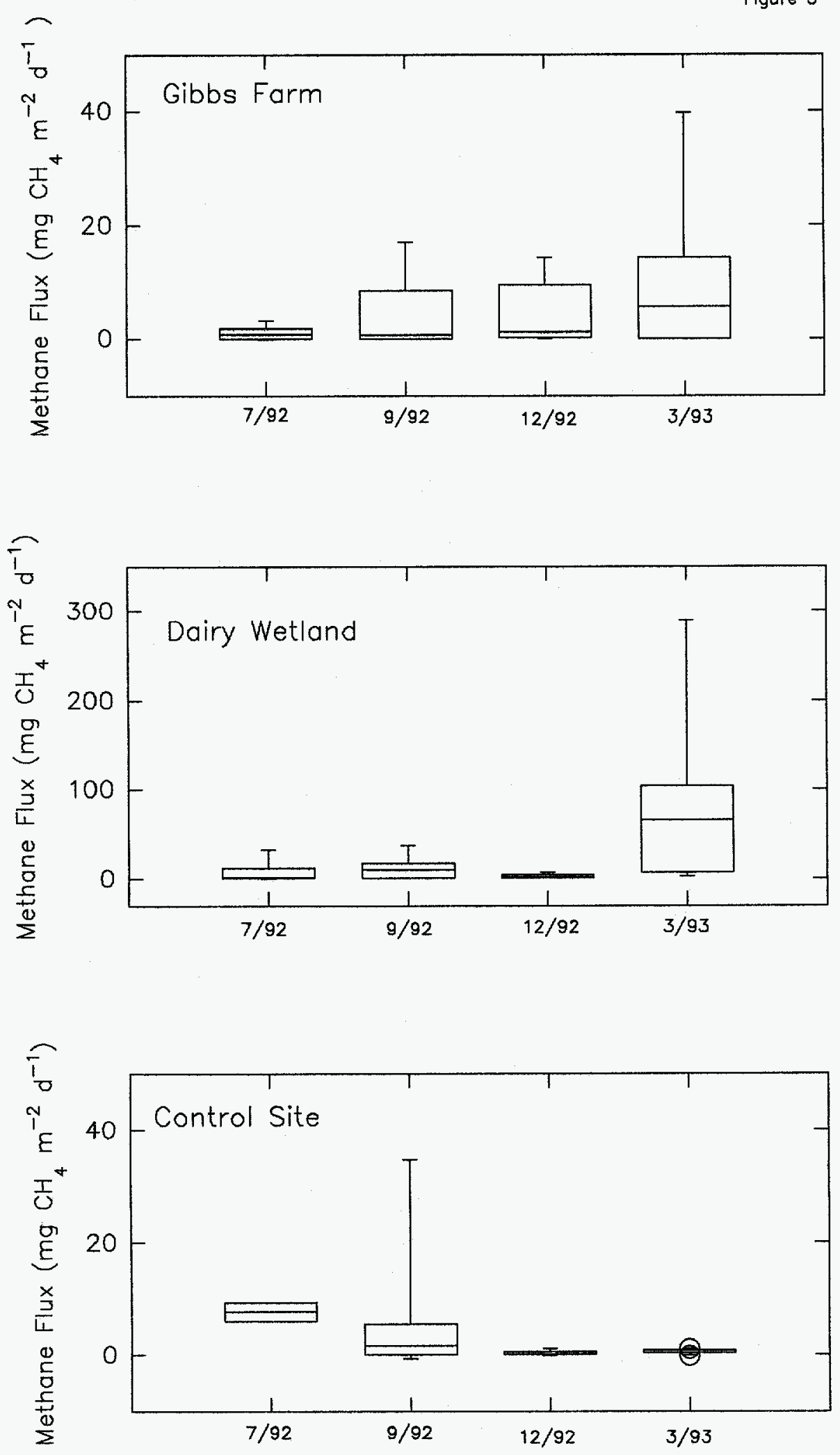


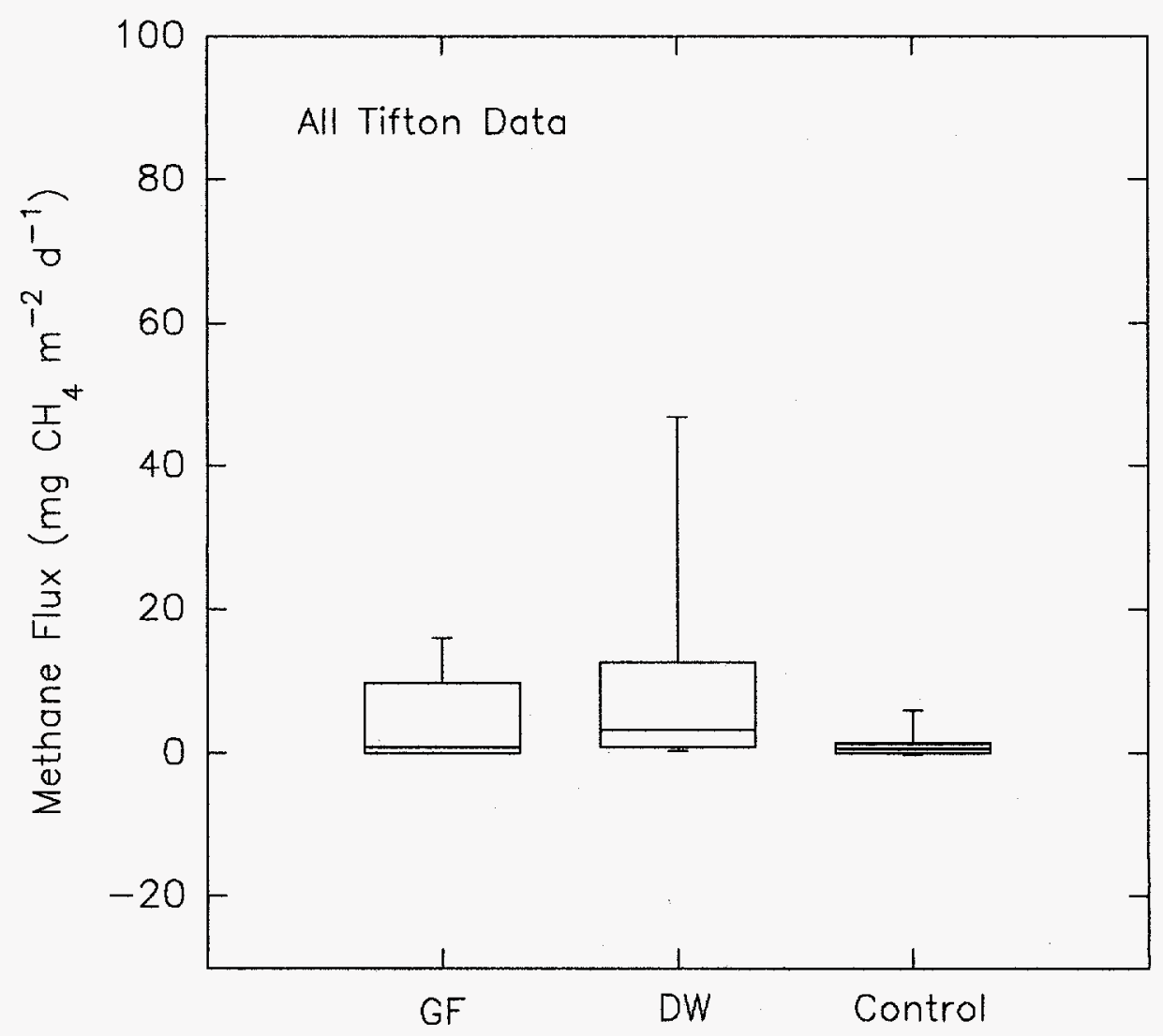

\section{DISCLAIMER}

This report was prepared as an account of work sponsored-by an agency of the United States Government. Neither the United States Government nor any agency thereof, nor any of their employees, makes any warranty, express or implied, or assumes any legal liability or responsibility for the accuracy, completeness, or usefulness of any information, apparatus, product, or process disclosed, or represents that its use would not infringe privately owned rights. Reference herein to any specific commercial product, process, or service by trade name, trademark, manufacturer, or otherwise does not necessarily constitute or imply its endorsement, recommendation, or favoring by the United States Government or any agency thereof. The views and opinions of authors expressed herein do not necessarily state or reflect those of the United States Government or any agency thereof. 